\title{
Impact of Convalescent Plasma Transfusion (CCP) In Patients With Previous Circulating Neutralizing Antibodies (nAb) to COVID-19
}

Ana Paula H Yokoyama 1, Silvano Wendel 2, Carolina Bonet-Bub 1, Roberta M Fachini

2, Ana Paula F Dametto 1, Fernando Blumm 4, Valeria F Dutra 1, Gabriela Candelaria 2, Araci M Sakashita 1, Rafael Rahal Guaragna Machado 6, Rita Fontao-Wendel 2, Nelson Hamerschlak 1, Ruth Achkar 2, Murillo Assuncao 1, Patricia Scuracchio 2, Victor Nudelman 1, Laerte Pastore 3, Joao R R Pinho 1, Mirian Dal Ben 3, Roberto Kalil Filho 3,7, Alexandre R. Marra 1,5, Mariane T. Amano ${ }^{3}$, Esper Kallas 3,8, Alfredo Salim Helito 3, Carlos Roberto Ribeiro de Carvalho 3,9, Danielle Bastos Araujo 1,6, Edison Luiz Durigon 6,10, Anamaria A Camargo ${ }^{3}$, Luiz V Rizzo ${ }^{1}$, Luiz F Lima Reis ${ }^{3}$, Jose M Kutner ${ }^{1}$

1 Hospital Israelita Albert Einstein, Sao Paulo, Brazil

2 Hospital Sirio-Libanes Blood Bank, Sao Paulo, Brazil

3 Hospital Sirio-Libanes, Sao Paulo, Brazil

4 Hospital Sirio-Libanes, Brasilia, Brazil

5 Office of Clinical Quality, Safety, and Performance Improvement, University of Iowa Hospitals and Clinics, Iowa City, Iowa

6 Department of Microbiology, Institute of Biomedical Sciences, University of Sao Paulo, Sao Paulo, Brazil

7 University of Sao Paulo - Heart Institute (Incor), Sao Paulo, Brazil

8 Department of Infectious and Parasitic Diseases, School of Medicine, University of Sao Paulo, Sao Paulo, Brazil

9 Cardio-Pulmonary Department, Pulmonary Division, Heart Institute (Incor), University of Sao Paulo, Sao Paulo, Brazil

10 Scientific Platform Pasteur USP, Sao Paulo, Brazil

* Conflict of interests: DBA by Grant $88887.131387 / 2016-00$ (CAPES), RRGM by Grant 2017/24769-2 (FAPESP) and ELD by Grants 2016/20045-7 and 2020/06409-1 (FAPESP). This project was partially supported by the initiative "Todos Pela Saude" - Fundacao Itau para Educacao

Cultura. 


\section{Abstract}

INTRODUCTION: COVID-19 convalescent plasma (CCP) transfusion has emerged in the past months as an alternative approach to treat pneumonia cases of SARS-CoV-2. Current evidence regarding characteristics of the plasma product, the titer of neutralizing antibodies (nAbs) in the transfused units, time to onset of intervention, and impact of nAbs produced by the patient are limited and heterogeneous.

MATERIAL AND METHODS: We describe the preliminary results of 104 patients with severe pneumonia due to SARS-CoV-2 transfused with CCP at three medical centers in Brazil. All enrolled patients were transfused with doses between $200 \mathrm{~mL}$ through $600 \mathrm{~mL}$ of $A B O$ compatible CCP on days 0-2 after enrolment. Clinical parameters were monitored and nAbs titration was performed using the cytopathic effect-based virus neutralization test with SARS-CoV-2 (GenBank MT126808.1).

RESULTS: Forty-one patients achieved clinical improvement on day 14 , and multivariable logistic regression showed that nAbs T (from CCP units transfused) $(p=0.001), n A b s$ PO (on day of enrolment) $(p=0.009)$ and use of other supportive therapies $(p<0.001)$ were associated with higher odds for this clinical improvement. Considering ICU length of stay (LOS) and length of mechanical ventilation, in our analysis, nAbs PO were associated with a significant reduction in ICU LOS ( $p=0.018)$ and duration of mechanical ventilation $(p<0.001)$. Administration of CCP after 10 days of symptom onset was associated with increases in ICU length of stay $(p<0.001)$.

DISCUSSION/CONCLUSION: Despite the study limitations, our data have shown an association between patients' previously acquired nAbs and clinical outcomes. The potential value of timely administration of CCP transfusion before day 10 of disease onset was demonstrated and nAbsPO, but not nAbsT, were associated with ICU LOS, and duration of mechanical ventilation on the improvement of clinical outcomes was also demonstrated. In conclusion, we consider these data are useful parameters to guide future CPP transfusion strategies to COVID-19. 


\section{Introduction}

COVID-19 convalescent plasma (CCP) transfusion has emerged in the past months as an alternative approach to treat pneumonia cases of Severe Acute Respiratory Syndrome Coronavirus 2 (SARS-CoV-2) [1,2]. Several specific therapies are still under development, with limited evidence towards efficacy and survival benefit $[3,4,5]$. Hence, given its rapid availability, CCP transfusion was proposed as an alternative therapy early in the course of Coronavirus 2019 (COVID-19) pandemics, with proven safety [6]. Historically, convalescent plasma has been used as an emergent strategy in many outbreaks, such as Spanish influenza, with reduced mortality rates [7]. Positive results have been described in other viral epidemics like Ebola [8], Severe Acute Respiratory Syndrome for Coronavirus (SARSCoV-1) [9], and Middle East Respiratory Syndrome (MERS-CoV) [10].

The rationale for CCP transfusion relies on the fact that convalescent individuals have circulating neutralizing antibodies (nAbs) able to suppress the infection [11]. Other immunomodulatory mechanisms, such as complement activation, antibody-dependent cytotoxicity, or phagocytosis are potential pathways through which CCP might alleviate systemic inflammation. Also, non-nAbs that bind to the virus, despite not interfering with replication capacity, might contribute to recovery [12]. Previous studies demonstrated that CCP transfusion was able to inhibit SARS-CoV-2 replication [13] and efficacy was associated with the concentration of nAbs in the plasma of convalescent donors [14]. However, data about the clinical impact of nAbs on COVID-19 outcomes are still sparse.

Current evidence regarding characteristics of the plasma product, the titer of nAbs in the transfused units, time to onset of intervention, and impact of nAbs produced by the patient are limited and heterogeneous, which precludes consistent conclusions from the available data. We describe here the preliminary results of 104 patients with severe pneumonia due to SARS-CoV-2 transfused with CCP at three medical centers in Brazil. 


\section{Materials and methods}

This was a single-arm prospective study conducted at three reference medical centers in Sao Paulo and Brasilia, Brazil. It was approved by the Brazilian National Commission for Research Ethics (CONEP), CAAE 30922420.6.2002.0071, and the Ethics Committees of each participating site. Informed Consent was obtained from all study participants or their legal representatives.

\section{Convalescent plasma collection}

CCP donors with laboratory-confirmed COVID-19 diagnosis by reverse transcriptasepolymerase chain reaction (RT-PCR), fully recovered and asymptomatic for at least 14 days were recruited on participating sites. Donor screening comprised Brazilian regular criteria for blood donation and negative RT-PCR from blood or naso-oropharyngeal swabs collected on the day of donation. Serum for determination of SARS-CoV-2 nAbs from each donor was also collected on the day of donation for further analysis. Convalescent plasma products were obtained from whole blood or plasmapheresis donations [15], and approximately 50\% of units were pathogen-inactivated using amotosalen/UVA illumination (INTERCEPT, Cerus corporation, Concord, CA USA).

\section{Patients}

From April 11 through October 25, 104 patients admitted to participating sites with COVID19 confirmed diagnosis by RT-PCR, \&[gt]18 years of age, with criteria for severe pneumonia (defined by respiratory distress: oxygen saturation of $93 \%$ or less on room air, respiratory rate $>30$ breaths/min and/or arterial partial pressure of oxygen $\left(\mathrm{PaO}_{2}\right) /$ fraction of inspired oxygen $\left(\mathrm{FiO}_{2}\right)$ of 300 or less) were included. Patients with preexisting history of anaphylactic transfusion reaction, pregnant or lactating women were excluded.

\section{Intervention}

All enrolled patients were transfused with doses between $200 \mathrm{~mL}$ through $600 \mathrm{~mL}$ of $A B O$ compatible CCP on days 0-2 after enrolment, with close monitoring. Criteria for higher volumes of CCP were at the assistant physician's discretion but included mechanical 
ventilation and/or absence of clinical improvement within 2 days from the first CCP transfusion. CCP units with nAbs titers \&[gt]160 were transfused, except for the first eleven patients included in the first two weeks of the study, when nAbs from CCP units were not available before transfusion, comprising sixteen CCP doses, with $\mathrm{nAb}$ geometric mean titer ranging from 20 to 640 . No other interventions on supportive COVID-19 treatment were made by the research staff. Clinical and laboratory information were collected until discharge: baseline demographic data, comorbidities, laboratory parameters, days of illness onset before hospital and ICU admission, other COVID-19 supportive therapies and mechanical ventilation. Titration of $n A b s$ was performed using the cytopathic effect-based virus neutralization test (CPE-based VNT) with SARS-CoV-2 (GenBank MT126808.1) [16] with patient samples on the day of enrolment (day 0) (nAbs P0) and on day 5 (nAbs P5) after CCP transfusions. Clinical status of patients was assessed according to severity organ failure assessment (SOFA) score on day 0 and evolution was assessed with adapted World Health Organization (WHO) ordinal scale [17] (table 1) on days 0 , 5, and 14. Intensive care unit (ICU) and hospital length of stay, duration of mechanical ventilation, and disease evolution were registered.

\section{Outcomes}

The primary outcome was a clinical improvement on day 14, defined as a reduction of at least two points on an adapted WHO ordinal scale. Secondary outcomes were intensive care unit length of stay (ICU LOS) and duration of invasive mechanical ventilation.

\section{Statistical Analysis}

Baseline characteristics were described as counts and percentages for categorical variables or mean and standard deviation (SD) for continuous variables with a normal distribution. Median and interquartile range (IQR) were used to describe continuous variables with asymmetrical distribution. Univariate and multivariate regression models were adjusted to assess the outcomes: intensive care unit (ICU) length of stay, duration of mechanical ventilation, and clinical improvement on day 14 (binary). Explanatory variables considered were: mean geometric titer of Nabs from CP units transfused (NAbsT), neutralizing antibody titers from patients before transfusion (NAbsPO), neutralizing antibody titers from patients on Day 5 (NAbsP5), the total volume of CP transfused, age, gender, weight, ABO group, 
medRxiv preprint doi: https://doi.org/10.1101/2020.12.08.20246173; this version posted December 11, 2020. The copyright holder for this preprint (which was not certified by peer review) is the author/funder, who has granted medRxiv a license to display the preprint in perpetuity. It is made available under a CC-BY-NC-ND 4.0 International license .

severity organ failure assessment score on admission day (SOFA DO), use of other supportive therapies for COVID-19 (azithromycin, hydroxychloroquine, steroids, tocilizumab, human immunoglobulin, antiviral therapies), and comorbidities. To analyze if earlier CP transfusion had an impact on outcomes, we also analyzed if CP transfusion was performed up to 10 days of disease onset or later. For each outcome, we performed a generalized estimating equations model to account for the dependence of data collected at each of the three institutions. For mechanical ventilation, we used negative binomial distribution and for ICU LOS we used gamma distribution, both with log link functions. Clinical improvement on day 14 was assessed with a binomial distribution and logit link function. Results were presented as mean ratios (MR) or odds ratios (OR) with $95 \%$ confidence intervals and $p$ values, p\&[It]0.05 was considered statistically significant. For the analysis, we used IBM SPSS Statistics for Windows, Version 24.0. 2016, R package [18], and ggplot2 [19]. 


\section{Results}

Mean age of patients was 64 years (SD: + /- 15 yrs), 74 patients (71.1\%) were male, and 93 (89.4\%) had different comorbidities - arterial hypertension was present in $51.9 \%$ of the individuals, diabetes mellitus in $29.8 \%$ and $34.6 \%$ were obese. The median body weight was $84 \mathrm{~kg}$. Regarding the ABO blood group, 45 (45.2\%) were A individuals, $44(42.3 \%)$ were 0,10 were $B(9.6 \%)$ and $3(2.9 \%)$ were $A B$. The vast majority of patients $(82.7 \%)$ also received other therapies (azithromycin, hydroxychloroquine, tocilizumab and/or combinations). Fiftyone patients $(49 \%)$ required invasive mechanical ventilation. NAbs from patients on day 0 (immediately before CCP transfusions - NAbsPO) varied from 10 to $1240\left[1^{\text {st }}\right.$ IQR $640-3^{\text {rd }}$ IQR 5120]. To consider the dose-effect of $n A b s$ on each outcome, the total amount of $n A b s$ were calculated using geometric mean nAbs titer from CCP units (NAbsT), which varied from 20 to 3044 [ $1^{\text {st }} I Q R$ 254- $3^{\text {rd }} I Q R$ 640]. Three patients received doses of $200 \mathrm{ml}$ (2.9\%), nineteen patients received doses of $300 \mathrm{ml}$ (18.2\%), 23 patients received $400 \mathrm{ml}(22.8 \%)$ and 59 received $600 \mathrm{ml}$ (56.7\%) (Table 1). CCP transfusions were well-tolerated and 5 (4.8\%) mild to moderate transfusion reactions occurred: 3 febrile non-hemolytic reactions, 2 allergic reactions. Two suspected cases were screened for TRALI, with negative results. Of note, only plasma from male, nulliparous women, or women with a history of up to 2 gestations and negative HLA screening (Lifecodes lifescreen Deluxe - Immucor) were suitable for CCP donation. No severe adverse events were observed. Six (5.7\%) had thromboembolic events (TE) after CCP infusion, even under thrombotic prophylaxis or on full anticoagulation due to TE diagnosed before the enrolment. These rates are somewhat lower than the rates observed in hospital COVID patients in general $[20,21]$

Figure 1 shows the timeline of clinical evolution after the onset of illness (OIL) for the 104 patients. Median times from OIL to hospital admission was 6.5 days [ $1^{\text {st }}$ IQR $3-3^{\text {rd }}$ IQR 9.9], and from OIL to dyspnea was 6 days [IQR 3-8]. Median times from OIL to ICU admission was 8.7 days [IQR 5.4-11.0] and from OIL to CCP transfusion was 10 days [ $1^{\text {st }}$ IQR $8.0-3 \mathrm{rd}$ IQR 13.0].

Clinical improvement was assessed by the World Health Organization scale score at days 0,5 and, 14. By day 5, 19 (18.2\%) patients have achieved clinical improvement. On day 14 , the proportion of patients who had improved raised to $41 \%$, with $49.4 \%$ of patients with mild 
disease (WHO ordinal scale between 0-4) and 38 (36.5\%) had already been discharged.

There were eleven deaths (10.5\%), and one event happened before day 7 after CCP transfusion (figure 2).

Multivariable analysis showed that circulating nAbs developed by the patients before transfusion (NAbsP0) (OR=1.261; Cl95\%: 1.059-1.502, $\mathrm{p}=0.009$ ), mean geometric nAbs titer from transfused CCP units (NAbsT) (OR=1.327; Cl95\%: 1.119-1.574, $p=0.001$ ) and use of other supportive therapies for COVID-19 (OR=3.347; CI95\%: 1.781-6.288, $p<0.001$ ) are associated with higher odds of clinical improvement on day 14. On the contrary, SOFA score on day 0 (OR=0.573; $C 195 \%$ : 0.426-0.769, $\mathrm{p}<0.001$ ) and total $\mathrm{CCP}$ volume transfused (OR= 0.631; $\mathrm{Cl} 95 \%$ : 0.555-0.717, $\mathrm{p}<0.001$ ) were associated with lower chances of clinical improvement. Age, gender, $\mathrm{ABO}$ group, time from onset of illness until CCP transfusion, comorbidities, and exposure to other therapies had no impact on 14-day clinical improvement.

We sought to determine predictive variables for the duration of mechanical ventilation and ICU LOS. Duration of mechanical ventilation was available for 36 patients. Data from 11 patients who died and 4 patients who have not been discharged at the end of the analysis were not considered for this evaluation. Mechanical ventilation support varied from 3 to 61 days, median duration was 10 days [ $1^{\text {st }}$ IQR $5-3^{\text {rd }}$ IQR 16 ]. Logistic regression models were performed to identify predictive variables. Multivariable analysis showed that level of patient nAb titers prior to transfusion (NAbsP0) (Mean ratio MR=0.961; Cl95\%:0.951-0.972, $p<0.001)$, SOFA score on day 0 ( $M R=1.180 ; C l 95 \%: 1.142-1.221, p<0.001)$, age ( $M R=0.978$; Cl95\%: 0.963-0.992, $\mathrm{p}<0.003$ ) and body weight ( $M R=0.992 ; C 195 \%: 0.989-0.994, p<0.001)$ were independently associated to duration of mechanical ventilation support. The higher the NAbsPO before CCP infusion, the shorter the need for mechanical ventilation support. Paradoxically to what has been described in the medical literature $[22,23,24]$, older patients and more obese were also associated with shorter durations of invasive mechanical ventilation. The severity of patients assessed with SOFA score also revealed associations with longer periods of mechanical ventilation support. Other variables failed to provide associations with the length of mechanical ventilation support.

We also analyzed predictive variables for ICU LOS. Multivariate logistic regression showed that higher NAbsPO (MR=0.975; Cl95\%: 0.955-0.996, $p<0.018$ ) were associated with shorter 
medRxiv preprint doi: https://doi.org/10.1101/2020.12.08.20246173; this version posted December 11, 2020. The copyright holder for this preprint (which was not certified by peer review) is the author/funder, who has granted medRxiv a license to display the preprint in perpetuity. It is made available under a CC-BY-NC-ND 4.0 International license .

periods of ICU LOS. Conversely, time for transfusion after 10 days of symptom onset

(MR=1.665; Cl95\%: 1.494-1.857, $\mathrm{p}<0.001)$, presence of comorbidities (MR=2.125; Cl95\%:

1.497-3.016, $\mathrm{p}<0.001$ ), severity of the disease on day 0 ( $M R=1.195 ; \mathrm{Cl} 95 \%: 1.1155-1.235$, $\mathrm{p}<0.001)$ and age (MR=1.011; Cl 95\%: 1.006-1.017) were associated with longer periods in ICU. NAbs T showed no statistical significance on reduction of ICU LOS (MR=0.880; CI95\%: $0.726-1.066, p=0.190$ ) 


\section{DISCUSSION}

We report our experience with CCP transfusion in 104 severe critically ill patients with COVID-19. The first data drawn from this study is that CCP is a safe procedure, where no major hazard effects were observed in this group of severe patients. CCP transfusion is based on the fact that it provides nAbs able to reduce the viral burden and prevent systemic manifestations in susceptible patients [25]. Several observational studies reported data favoring the efficacy of convalescent plasma [26, 27, 28]. Conversely, recently published randomized clinical trials on convalescent plasma for COVID-19 [29,30,31] showed no benefit on mortality or clinical improvement on day 30 [32]. Also, a systematic review analyzing CCP and hyperimmune immunoglobulin failed to provide robust evidence regarding the clinical efficacy of both products [33], highlighting the need for more research on this field.

We analyzed predictive factors for clinical improvement on day 14. Forty-one patients achieved clinical improvement, and multivariable logistic regression showed that $n A b s T$ ( $p=$ $0.001)$, nAbs PO ( $p=0.009)$, and use of other supportive therapies ( $p<0.001)$ were statistically associated with higher odds of clinical improvement. At each -500 unit increase in nAbs T, the odds of clinical improvement raised by $32.7 \%$. Median geometric nAbs was 403.2 , interquartile range 254-640. Our findings differ from previous studies on CCP efficacy. A randomized controlled trial published by Gharbharan et al, although prematurely halted, showed no difference $(p=0.58)$ on improvement in disease severity by day 15 . The PLACID trial [30] also failed to provide evidence in favor of CCP transfusion, once plasma was not associated with a reduction in progression to disease severity at 28 days. No significant differences in clinical improvement or overall mortality were observed by Simonovitch et al [32], who transfused CCP units with median nAbs titer similar to ours (median nAbs: 300, interquartile range 136-511). It is still unknown if higher titer nAbs would have resulted in better outcomes. We acknowledge that CCP transfusion impacts on clinical improvement as a modest effect (OR 1.327, Cl95\% 1.119-1.574 p: 0.001), as opposed to the impact of using other COVID 19 supportive therapies (OR 3.347 CI95\% 1.781-6.288, $\mathrm{p}<0.001$ ). More research is still needed to better clarify the benefit of CCP in clinical improvement.

Considering ICU LOS and length of mechanical ventilation, in our analysis, nAbs PO, but not nAbsT, were associated with a significant reduction in ICU LOS $(p=0.018)$ and duration of 
mechanical ventilation $(p<0.001)$. At each -500 unit increase on the mean geometric titer of nAbsPO, a $2.5 \%$ reduction on ICU LOS was expected and a 3.9\% reduction on the duration of mechanical ventilation. On the contrary, nAbs Thad no impact on these same outcomes. Our findings reinforce the fact that patient nAbs and not nAbs from transfused CCP units may determine the outcome in severe disease. Accordingly, Wang et al [34] showed that patients with more severe symptoms tended to have higher antibody titers. Hence, CCP transfusion might not add benefit in this scenario, and antibody screening before CCP transfusion could be useful to identify potential individuals who could benefit from this passive therapy [29]. This is important especially on critically ill patients, reported having solid antibody response. In our study, data about the nAbs status of patients were not available before CCP transfusion and such analysis was not possible.

Also, our findings show that timely administration of CCP is relevant for clinical outcomes. Administration of CCP after 10 days of symptom onset was associated with increases in ICU length of stay in a statistically significant manner $(p<0.001)$. Antibody responses to SARSCoV-2 seem to appear between 2 -3 weeks after initiation of symptoms [35] and nAbs specifically reach their peak within 10-15 days after disease onset [36]. In a prematurely interrupted randomized trial, transfusion of CCP in later stages did not result in significant clinical improvement within 28 days compared to standard treatment [31]. In this study, the median time from disease onset to CCP intervention was 30 days, twice the period from ours. On the other hand, in a case-control study published by Liu et al [2], CCP transfusion was administered with a median time of 7 days from admission to transfusion. Improvements in survival in patients not on mechanical ventilation support and decreased oxygen requirements were observed. Taken this study with ours are following the fact that earlier initiation of passive immunotherapy might provide better outcomes. [2,27, 37,38,39].

We also observed that the severity of the disease at day 0 (SOFA DO), age, and comorbidities, in general, was associated with increases in ICU length of stay. However, these findings were not reproducible in the duration of mechanical ventilation. Our data partially differs from Gamberini et al, who demonstrated that age, SOFA score at ICU admission, $\mathrm{PaO}_{2} / \mathrm{FiO}_{2}$, renal and cardiovascular complications, and late-onset VAP were all independent risk factors for prolonged mechanical ventilation in patients with COVID-19 [40]. Differences found may be due to the low number of patients analyzed and different methodologies implemented. 
medRxiv preprint doi: https://doi.org/10.1101/2020.12.08.20246173; this version posted December 11, 2020. The copyright holder for this preprint (which was not certified by peer review) is the author/funder, who has granted medRxiv a license to display the preprint in perpetuity. It is made available under a CC-BY-NC-ND 4.0 International license .

Despite the study limitations such as the size of the cohort and the fact that it is a one-arm prospective study, our data have shown an association between patients' previously acquired nAbs and clinical outcomes. Our analysis also suggests that nAbsT was associated with clinical improvements on day 14. Besides, nAbsPO but not nAbsT have an impact on ICU LOS and duration of mechanical ventilation. The potential value of timely administration of CCP transfusion before day 10 of disease onset on the improvement of clinical outcomes was also demonstrated. In conclusion, we consider these data are useful parameters to guide future CPP transfusion strategies to COVID-19. 
medRxiv preprint doi: https://doi.org/10.1101/2020.12.08.20246173; this version posted December 11, 2020. The copyright holder for this preprint (which was not certified by peer review) is the author/funder, who has granted medRxiv a license to display the preprint in perpetuity.

It is made available under a CC-BY-NC-ND 4.0 International license .

\section{Tables and Figures}

Figure 1. Timeline of COVID-19 patients included in the study

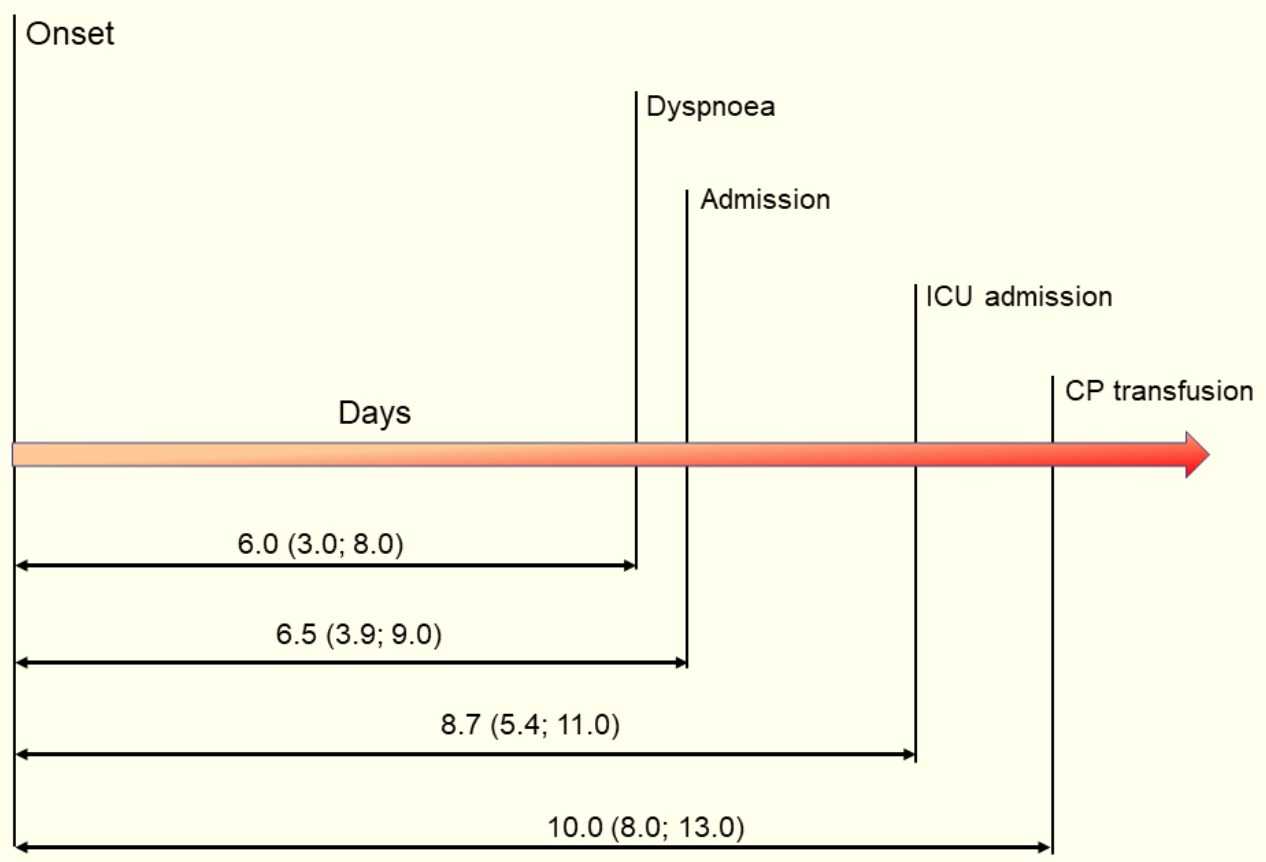

Median (1st quartile; 3rd quartile) 
medRxiv preprint doi: https://doi.org/10.1101/2020.12.08.20246173; this version posted December 11, 2020. The copyright holder for this preprint (which was not certified by peer review) is the author/funder, who has granted medRxiv a license to display the preprint in perpetuity.

It is made available under a CC-BY-NC-ND 4.0 International license .

Table 1. Demographic and Clinical data of studied patients

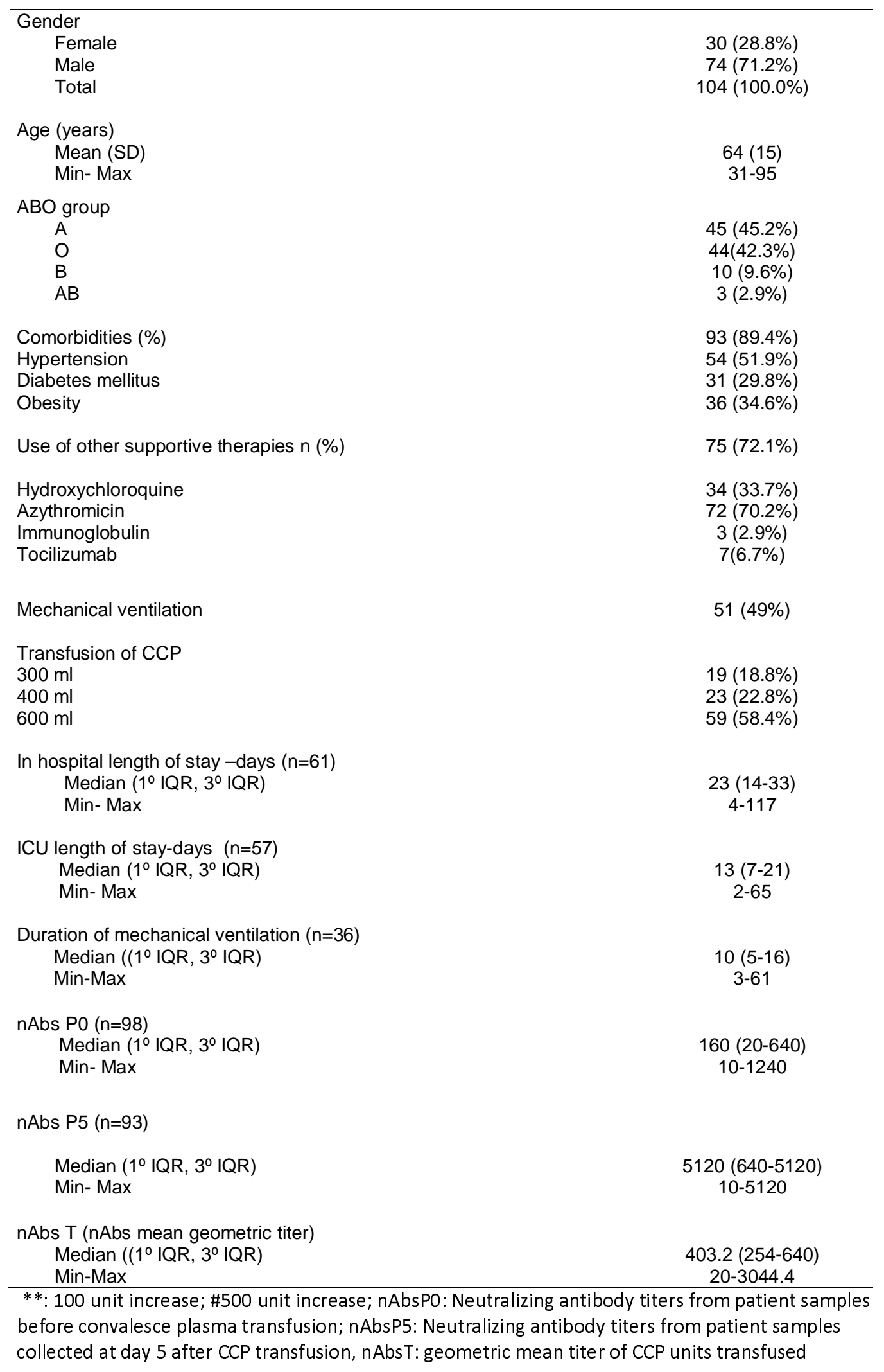


Table 2. Clinical improvement on Day 14 post-CCP transfusion

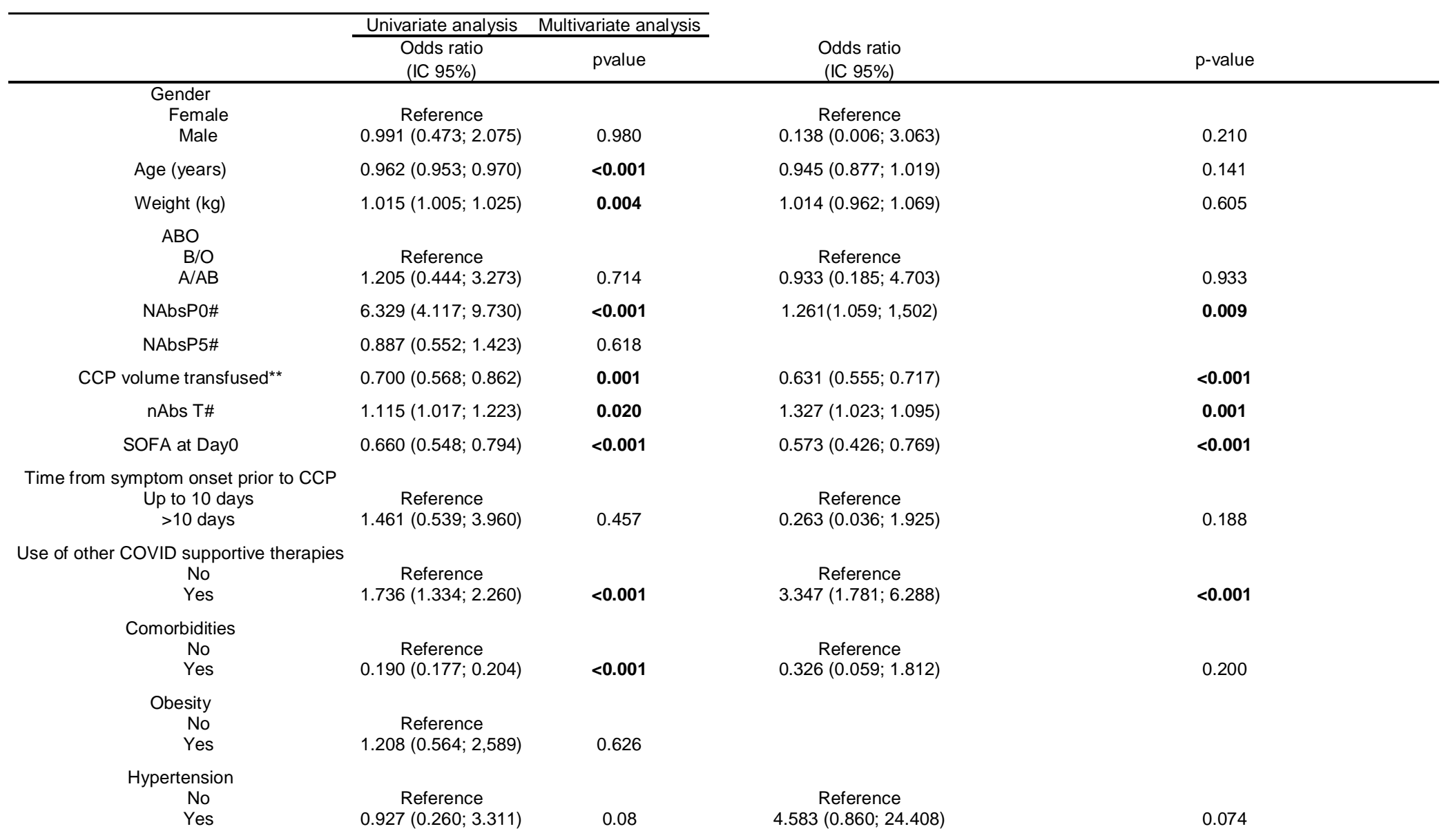




\section{Diabetes mellitus}

No

Reference

$0.303(0.156 ; 0.589)$

$<0.001$

Reference

$0.306(0.068 ; 1.384)$

0.124

**: 100 un it increase; \#500 unit increase; nAbsPO: Neutralizing antibody titers from patient samples before convalescent plasma transfusion; nAbsP5:

nAb titers from patient samples collected at day 5 after CCP transfusion, nAbsT: geometric mean titer of CCP units transfused 
medRxiv preprint doi: https://doi.org/10.1101/2020.12.08.20246173; this version posted December 11, 2020. The copyright holder for this preprint (which was not certified by peer review) is the author/funder, who has granted medRxiv a license to display the preprint in perpetuity.

It is made available under a CC-BY-NC-ND 4.0 International license .

Figure 2. Clinical Improvement on Day 14 post-CCP transfusion

Adjusted multiple model for reduction $\geq 2$ on the css score

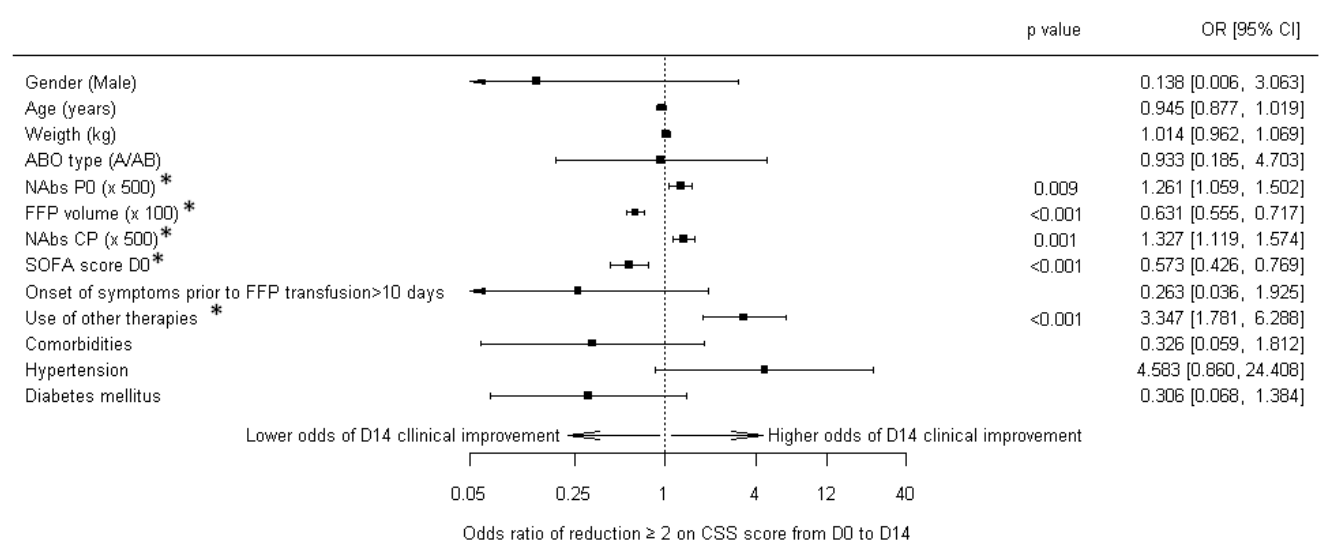

Obs. Left side means worse performance, right side means better performance. *Means had statistical significance Nabs PO = samples patients neutralizing antibodies measured on day of enrolment; FFP volume $=$ fresh frozen plasma volume; $\mathrm{nAbs} \mathrm{CP}=$ neutraziling antibodies from the convalescent plasma. Variables without a $p$ value means $p$ was non-significant. 
Table 3. Duration of mechanical ventilation post-CCP transfusion

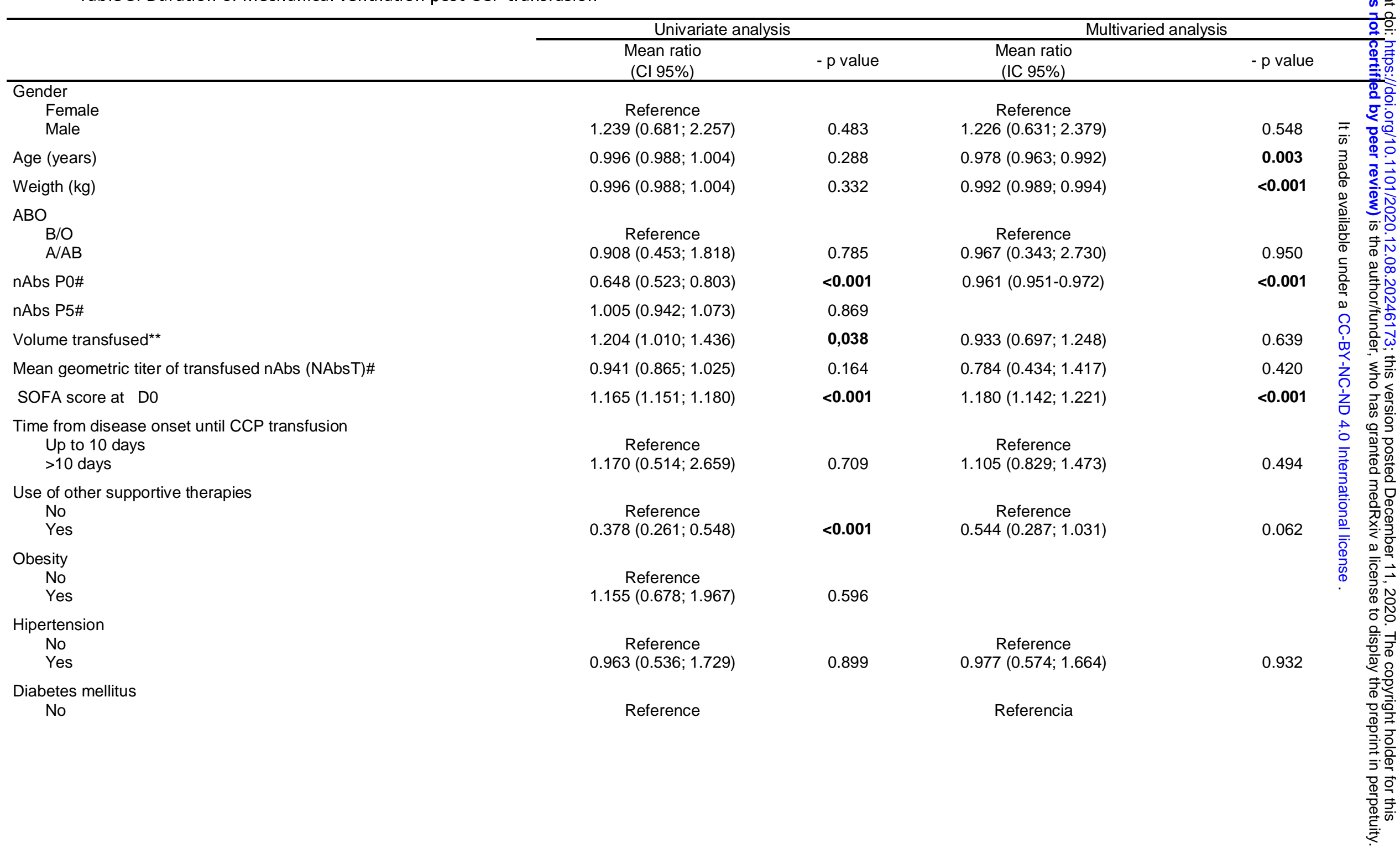


**: 100 unit increase; \#500 unit increase; nAbsPO: Neutralizing antibody titers from patient samples before convalesce plasma transfusion; NAbsP5: Neutralizing antibody titers from patient samples collected at day 5 after CCP transfusion, NAbsT: geometric mean titer of CCP units transfused 
medRxiv preprint doi: https://doi.org/10.1101/2020.12.08.20246173; this version posted December 11, 2020. The copyright holder for this preprint (which was not certified by peer review) is the author/funder, who has granted medRxiv a license to display the preprint in perpetuity.

It is made available under a CC-BY-NC-ND 4.0 International license .

Figure 3. Duration of Mechanical Ventilation post-CCP transfusion

Adjusted multiple model for Duration of mechanical ventilation

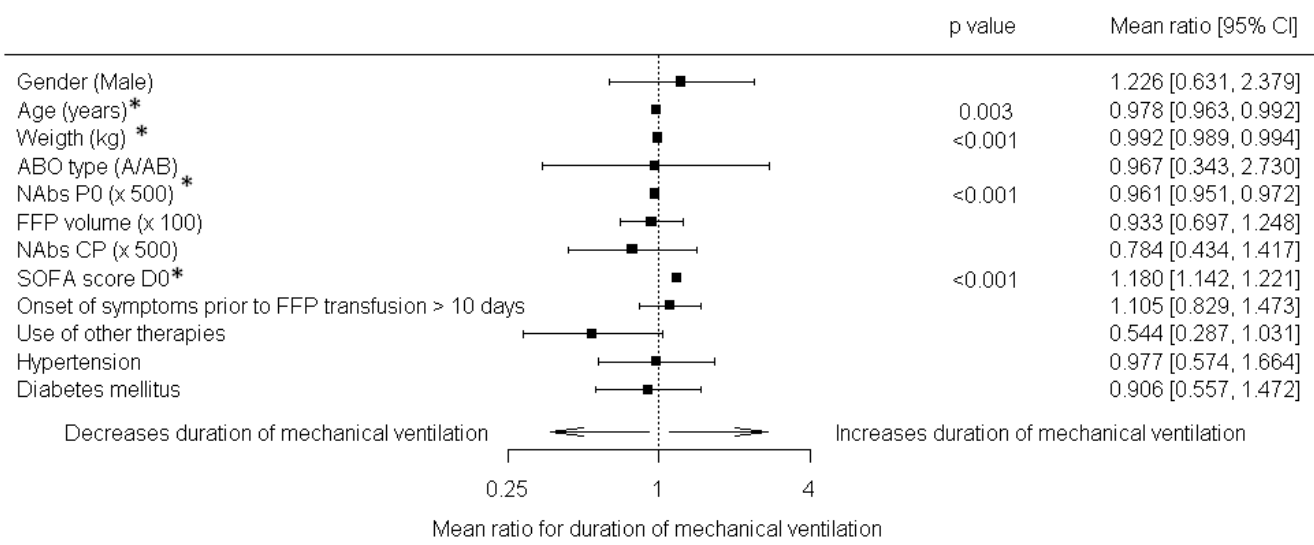

Obs. Left side means worse performance, right side means better performance. * Means had statistical significance. Nabs PO = samples patients neutralizing antibodies measured on day of enrolment; FFP volume $=$ fresh frozen plasma volume; $\mathrm{nAbs} C P=$ neutraziling antibodies from the convalescent plasma. Variables without a $p$ value means $p$ was non-significant. 
Table 4. ICU length of stay post-CCP transfusion

\begin{tabular}{|c|c|c|c|c|c|}
\hline & Univariate an & & & & \\
\hline & $\begin{array}{l}\text { Mean ratio } \\
\text { (IC 95\%) }\end{array}$ & pvalue & $\begin{array}{l}\text { Mean ratio } \\
\text { (IC 95\%) }\end{array}$ & $P$ value & \\
\hline $\begin{array}{l}\text { Gender } \\
\text { Female } \\
\text { Male }\end{array}$ & $\begin{array}{c}\text { Reference } \\
0.854(0.649 ; 1.123)\end{array}$ & 0.258 & $\begin{array}{c}\text { Reference } \\
0.950(0.770 ; 1.173)\end{array}$ & 0.636 & \\
\hline Age (years) & $1.020(1.016 ; 1.025)$ & $<0.001$ & $1.011(1.006 ; 1.017)$ & $<0.001$ & \\
\hline Weigth (kg) & $1.002(0.994 ; 1.010)$ & 0.654 & $1.005(0.999 ; 1.010)$ & 0.122 & \\
\hline $\begin{array}{l}\mathrm{ABO} \\
\mathrm{B} / \mathrm{O} \\
\mathrm{A} / \mathrm{AB}\end{array}$ & $\begin{array}{c}\text { Reference } \\
1.173(1.001 ; 1.375)\end{array}$ & 0.048 & $\begin{array}{c}\text { Reference } \\
1.044(0.732 ; 1.490)\end{array}$ & 0.811 & \\
\hline nAbs P0\# & $0.765(0.728 ; 0.805)$ & $<0.001$ & $0.975(0.955 ; 0.996)$ & 0.018 & D. \\
\hline nAbs P5\# & $1.013(0.990 ; 1.036)$ & 0.265 & & & \\
\hline Volume of CCP transfusion ${ }^{* *}$ & $1.246(1.108 ; 1.401)$ & $<0.001$ & $1.057(0.988 ; 1.131)$ & 0.105 & 笑 \\
\hline nAbs T\# & $0.959(0.912 ; 1.009)$ & 0.109 & $0.880(0.726 ; 1.066)$ & 0.190 & 2 \\
\hline SOFA score at DO & $1.212(1.072 ; 1.370)$ & 0.002 & $1.195(1.155 ; 1.235)$ & $<0.001$ & 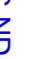 \\
\hline $\begin{array}{l}\text { Time from disease onset until transfusion } \\
\text { Uo to } 10 \text { days } \\
>10 \text { days }\end{array}$ & $\begin{array}{c}\text { Reference } \\
1.065(0.742 ; 1.527)\end{array}$ & 0.733 & $\begin{array}{c}\text { Reference } \\
1.665(1.494 ; 1.857)\end{array}$ & $<0.001$ & \\
\hline $\begin{array}{l}\text { Use of other supportive therapies } \\
\text { No } \\
\text { Yes }\end{array}$ & $\begin{array}{c}\text { Reference } \\
1.410(1.038 ; 1.917)\end{array}$ & 0.028 & $\begin{array}{c}\text { Reference } \\
1.280(0.949 ; 1.728)\end{array}$ & 0.106 & \\
\hline $\begin{array}{l}\text { Comorbidities } \\
\quad \text { No } \\
\text { Yes }\end{array}$ & $\begin{array}{c}\text { Reference } \\
4.058(3.260 ; 5.051)\end{array}$ & $<0.001$ & $\begin{array}{c}\text { Reference } \\
2.125(1.497 ; 3.016)\end{array}$ & $<0.001$ & \\
\hline $\begin{array}{l}\text { Obesity } \\
\text { No } \\
\text { Yes }\end{array}$ & $\begin{array}{c}\text { Reference } \\
1.282(1.046 ; 1.572)\end{array}$ & 0.017 & & & \\
\hline $\begin{array}{l}\text { Hyoertension } \\
\text { No }\end{array}$ & Reference & & Reference & & \\
\hline
\end{tabular}


increase, $\# 500$ unit increase, $\mathrm{AAbsPO}$. Neutralizing antibody titers

Neutralizing antibody titers from patient samples collected at day 5 after CCP transfusion, nAbsT: geometric mean titer of CCP units transfused 
medRxiv preprint doi: https://doi.org/10.1101/2020.12.08.20246173; this version posted December 11, 2020. The copyright holder for this preprint (which was not certified by peer review) is the author/funder, who has granted medRxiv a license to display the preprint in perpetuity.

It is made available under a CC-BY-NC-ND 4.0 International license .

Figure 4. ICU Length of Stay post-CCP transfusion

Adjusted multiple model for ICU length of stay

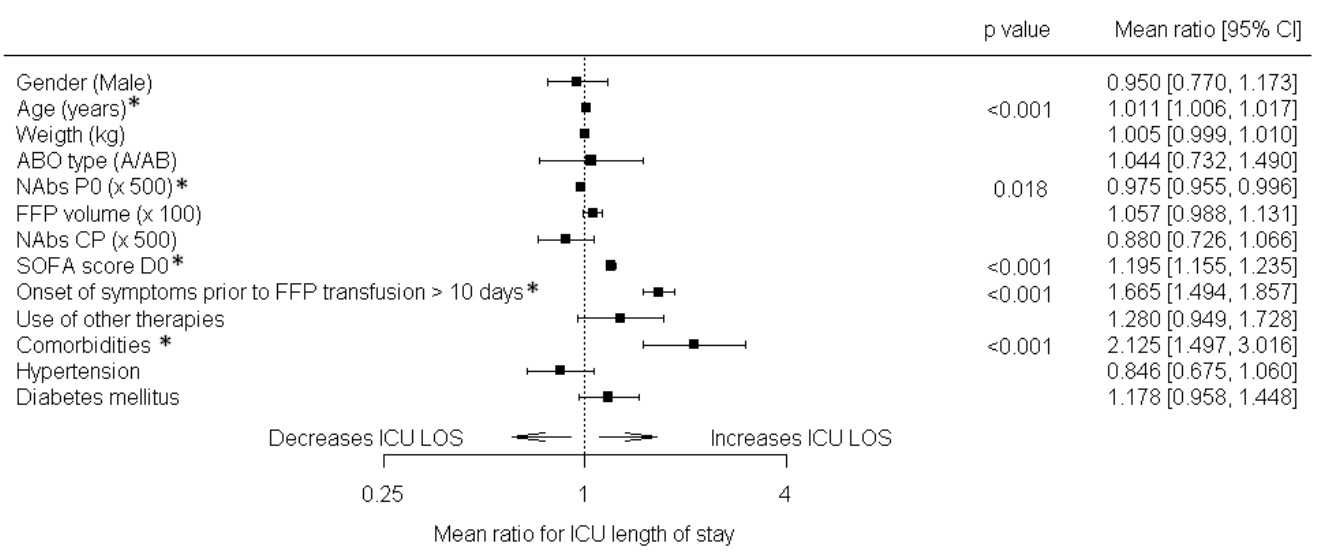

Obs. Left side means worse performance, right side means better performance. *Means had statistical significance $\mathrm{nAbs} \mathrm{PO}=$ samples patients neutralizing antibodies measured on day of enrolment; FFP volume $=$ fresh frozen plasma volume; $\mathrm{nAbs} C P=$ neutraziling antibodies from the convalescent plasma. Variables without a $p$ value means $p$ was non-significant. 
medRxiv preprint doi: https://doi.org/10.1101/2020.12.08.20246173; this version posted December 11, 2020. The copyright holder for this preprint (which was not certified by peer review) is the author/funder, who has granted medRxiv a license to display the preprint in perpetuity.

It is made available under a CC-BY-NC-ND 4.0 International license . 
medRxiv preprint doi: https://doi.org/10.1101/2020.12.08.20246173; this version posted December 11, 2020. The copyright holder for this preprint (which was not certified by peer review) is the author/funder, who has granted medRxiv a license to display the preprint in perpetuity. It is made available under a CC-BY-NC-ND 4.0 International license .

Figure 5. Adapted from OMS Score on days 0,5 , and 14 post-CCP transfusion

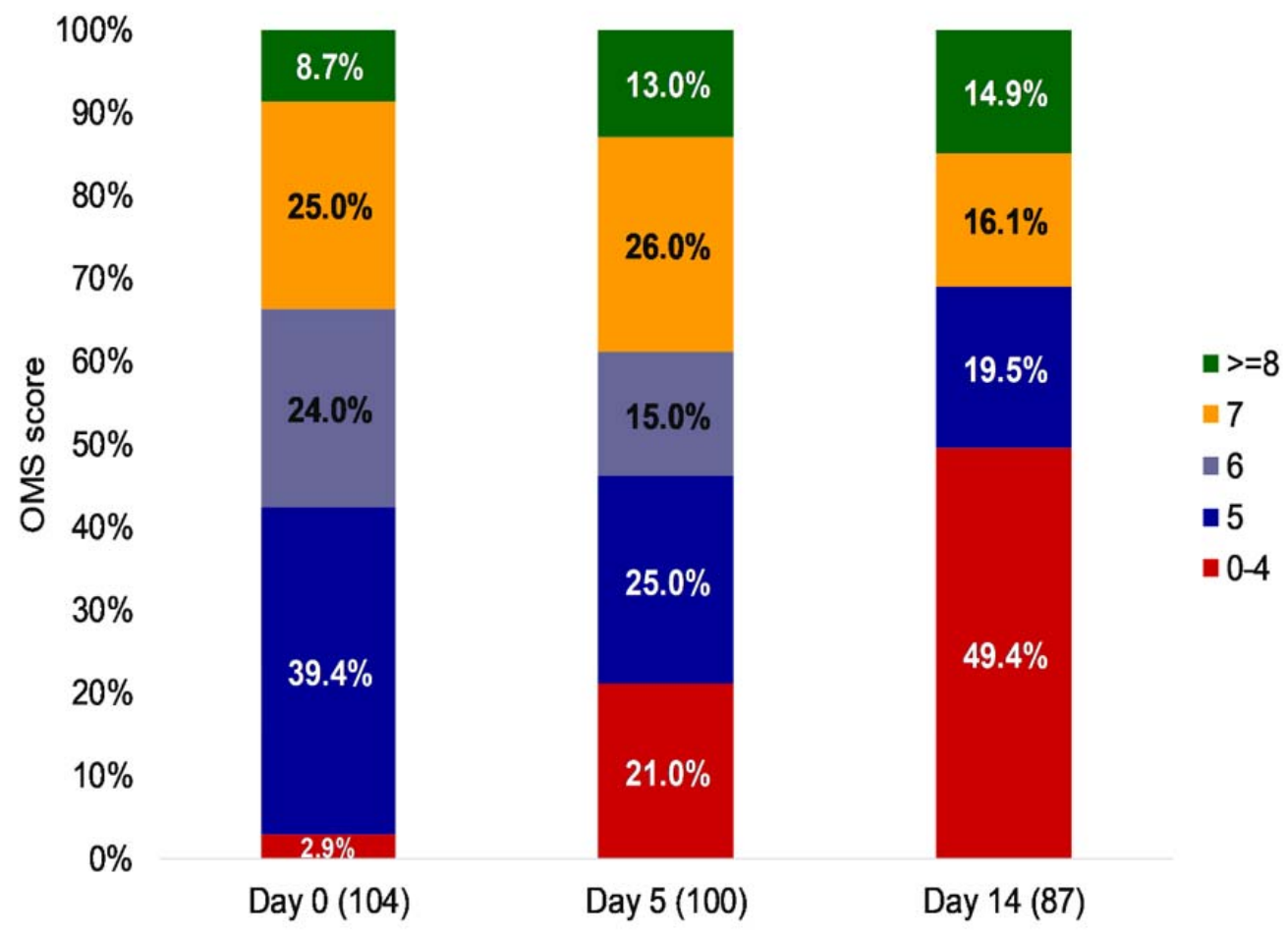




\section{References}

1-Li L, Zhang W, Hu Y, et al. Effect of Convalescent Plasma Therapy on Time to Clinical Improvement in Patients With Severe and Life-threatening COVID-19: A Randomized Clinical Trial. JAMA. 2020 Aug 4;324(5):460-470. doi: 10.1001/jama.2020.10044. Erratum in: JAMA. 2020 Aug 4;324(5):519. PMID: 32492084; PMCID: PMC7270883.

2-Liu STH, Lin H-M, Baine I, et al. Convalescent plasma treatment of severe COVID-19: A matched control study. medRxiv 2020:2020.05.20.20102236

3- Cao B, Wang Y, Wen D, et al. A Trial of Lopinavir-Ritonavir in Adults Hospitalized with Severe Covid19. N Engl J Med. 2020 May 7;382(19):1787-1799. doi: 10.1056/NEJMoa2001282. Epub 2020 Mar 18. PMID: 32187464; PMCID: PMC7121492.

4 - Beigel JH, Tomashek KM, Dodd LE, et al.; ACTT-1 Study Group Members. Remdesivir for the Treatment of Covid-19 - Final Report. N Engl J Med. 2020 Nov 5;383(19):1813-1826. doi: 10.1056/NEJMoa2007764. Epub 2020 Oct 8. PMID: 32445440; PMCID: PMC7262788.

5- Hung IF, Lung KC, Tso EY, et al. Triple combination of interferon beta-1b, lopinavir-ritonavir, and ribavirin in the treatment of patients admitted to hospital with COVID-19: an open-label, randomised, phase 2 trial. Lancet. 2020 May 30;395(10238):1695-1704. doi: 10.1016/S0140-6736(20)31042-4. Epub 2020 May 10. PMID: 32401715 ; PMCID: PMC7211500.

6- Joyner MJ, Wright RS, Fairweather D, et al. Early safety indicators of COVID-19 convalescent plasma in 5000 patients [published online ahead of print, 2020 Aug 10]. J Clin Invest. 2020;140200. doi:10.1172/JCl140200

7- Luke TC, Kilbane EM, Jackson JL, Hoffman SL. Meta-analysis: convalescent blood products for Spanish influenza pneumonia: a future H5N1 treatment?. Ann Intern Med. 2006;145(8):599-609. doi:10.7326/0003-4819-145-8-200610170-00139

8- Mupapa K, Massamba M, Kibadi K, et al. Treatment of Ebola hemorrhagic fever with blood transfusions from convalescent patients. International Scientific and Technical Committee. J Infect Dis 1999; 179(suppl 1):18-23.

9- Cheng $\mathrm{Y}$, Wong R, Soo YO, et al. Use of convalescent plasma therapy in SARS patients in Hong Kong. Eur J Clin Microbiol Infect Dis. 2005 Jan;24(1):44-6. doi: 10.1007/s10096-004-1271-9. PMID: 15616839; PMCID: PMC7088355. 10-

10 - Arabi YM, Hajeer AH, Luke T et al. Feasibility of Using Convalescent Plasma Immunotherapy for MERS-CoV Infection, Saudi Arabia Emerg Infect Dis. 2016 Sep;22(9):1554-61.

11- Casadevall A, Pirofski LA. The convalescent sera option for containing COVID-19. J Clin Invest. 2020 Apr 1;130(4):1545-1548. doi: 10.1172/JCI138003. PMID: 32167489; PMCID: PMC7108922.

12- Rojas M, Rodriguez Y, Monsalve DM, et al. Convalescent plasma in Covid-19: Possible mechanisms of action. Autoimmun Rev. 2020 Jul;19(7):102554. doi: 10.1016/j.autrev.2020.102554. Epub 2020 May 5. PMID: $32380316 ;$ PMCID: PMC7198427. 
13- Zhou G, Zhao Q Perspectives on therapeutic neutralizing antibodies against the Novel Coronavirus SARS-CoV-2. International Journal of Biological 2020; 16(10): 1718-1723. doi: 10.7150/ijbs.45123

14- van Griensven J, Edwards T, de Lamballerie X, et al. Evaluation of Convalescent 377 Plasma for Ebola Virus Disease in Guinea. N Engl J Med 2016; 374(1): 33-42.

15 - Wendel S, Kutner JM, Machado R, et al. Screening for SARS-CoV-2 antibodies in convalescent plasma in Brazil: Preliminary lessons from a voluntary convalescent donor program. Transfusion. 2020 Sep 16. doi: 10.1111/trf.16065. Online ahead of print.

16- Araujo DB, Machado RRG, Amgarten DE, et al. SARS-CoV-2 isolation from the first reported patients in Brazil and establishment of a coordinated task network. Mem Inst Oswaldo Cruz. 2020 Oct 23;115:e200342. doi: 10.1590/0074-02760200342. PMID: 33111751; PMCID: PMC7586445.

17-COVID-19 Therapeutic Trial Synopsis (c) World Health Organization 2020, downloaded at: https://www.who.int/publications/i/item/covid-19-therapeutic-trial-synopsis

18-R Foundation for Statistical Computing. R: A Language and Environment for Statistical Computing. 2018. https://www.R-project.org/.

19-Wickham. ggplot2: Elegant Graphics for Data Analysis: Springer-Verlag New York; 2016.

20- Middeldorp S, Coppens $M$, van Haaps TF, et al. Incidence of venous thromboembolism in hospitalized patients with COVID-19. J Thromb Haemost. 2020 Aug;18(8):1995-2002. doi: 10.1111/jth.14888. Epub 2020 Jul 27. PMID: 32369666; PMCID: PMC7497052

21- Klok FA, Kruip MJHA, van der Meer NJM, et al. Incidence of thrombotic complications in critically ill ICU patients with COVID-19.Thromb Res. 2020 Jul;191:145-147. doi: 10.1016/j.thromres.2020.04.013. Epub 2020 Apr 10.

22 -Li X, Xu S, Yu M, et al. Risk factors for severity and mortality in adult COVID-19 inpatients in Wuhan J Allergy Clin Immunol 2020 Jul;146(1):110-118. Doi:10.1016/j.jaci.2020.04.006. Epub 2020 Apr 12.

23 -Chen T, Wu D, Chen $\mathrm{H}$. Clinical characteristics of 113 deceased patients with coronavirus disease 2019: retrospective study BMJ 2020 Mar 26;368:m1091.doi: 10.1136/bmj.m1091.

24 -Hussaina A, Mahawar K, Xia Z. Obesity and mortality of COVID-19. Meta-analysis Obes Res Clin Pract Jul-Aug 2020;14(4):295-300. doi: 10.1016/j.orcp.2020.07.002

25- Imai M, Iwatsuki-Horimoto K, Hatta $M$, et al.. Syrian hamsters as a small animal model for SARSCoV-2 infection and countermeasure development. Proc Natl Acad Sci U S A. 2020 Jul 14;117(28):16587-16595. doi: 10.1073/pnas.2009799117. Epub 2020 Jun 22. PMID: 32571934; PMCID: PMC7368255.

26- Joyner MJ, Bruno KA, Klassen SA, et al. Safety Update: COVID-19 Convalescent Plasma in 20,000 Hospitalized Patients. Mayo Clin Proc. 2020 Sep;95(9):1888-1897. doi: 10.1016/j.mayocp.2020.06.028. Epub 2020 Jul 19. PMID: 32861333; PMCID: PMC7368917. 
27 - Duan K, Liu B, Li C, et al. The feasibility of convalescent plasma therapy in severe COVID- 19 patients: a pilot study. MedRxiv 2020.03.16.20036145; doi: https://doi.org/10.1101/2020.03.16.20036145

28- Rajendran K, Krishnasamy N, Rangarajan J, et al. Convalescent plasma transfusion for the treatment of COVID-19: Systematic review. J Med Virol. 2020 Sep;92(9):1475-1483. doi: 10.1002/jmv.25961. Epub 2020 May 12. PMID: 32356910; PMCID: PMC7267113.

29-Gharbharan, Jordans CCE, Geurtsvankessel C et al Convalescent Plasma for COVID-19. A randomized clinical trial. medRxiv preprint doi: https://doi.org/10.1101/2020.07.01.20139857

30- Agarwal A, Mukherjee A, Kumar G, et al. PLACID Trial Collaborators. Convalescent plasma in the management of moderate covid-19 in adults in India: open label phase II multicentre randomised controlled trial (PLACID Trial). BMJ. 2020 Oct 22;371:m3939. doi: 10.1136/bmj.m3939. Erratum in: BMJ. 2020 Nov 3;371:m4232. PMID: 33093056; PMCID: PMC7578662.

31- Li L, Zhang W, Hu Y, et al. Effect of Convalescent Plasma Therapy on Time to Clinical Improvement in Patients With Severe and Life-threatening COVID-19: A Randomized Clinical Trial. JAMA. 2020 Aug 4;324(5):460-470. doi: 10.1001/jama.2020.10044. Erratum in: JAMA. 2020 Aug 4;324(5):519. PMID: 32492084; PMCID: PMC7270883.

32- Simonovich VA, Burgos Pratx LD, et al. PlasmAr Study Group. A Randomized Trial of Convalescent Plasma in Covid-19 Severe Pneumonia. N Engl J Med. 2020 Nov 24. doi: 10.1056/NEJMoa2031304. Epub ahead of print. PMID: 33232588.

33- Chai KL, Valk SJ, Piechotta V, et al. Convalescent plasma or hyperimmune immunoglobulin for people with COVID-19: a living systematic review. Cochrane Database Syst Rev. 2020 Oct 12;10:CD013600. doi: 10.1002/14651858.CD013600.pub3. PMID: 33044747.

34-Wang X, Guo X, Xin Q. Neutralizing Antibodies Responses to SARS-CoV-2 in COVID-19 Inpatients and Convalescent Patients. MedRxiv preprint doi: https://doi.org/10.1101/2020.04.15.20065623

35- Callow KA, Parry HF, Sergeant M, Tyrrell DA. The time course of the immune response to experimental coronavirus infection of man. Epidemiol Infect. 1990 Oct;105(2):435-46. doi: 10.1017/s0950268800048019. PMID: 2170159; PMCID: PMC2271881.

36-Wu F, Wang AJ, Liu M, et al. Neutralizing Antibody Responses to SARS-CoV-2 in a COVID-19 Recovered Patient Cohort and their Implications. medRxiv 2020; published online Mar 30. DOI: 10.1101/2020.03.30.20047365

37- Salazar E, Christensen PA, Graviss EA, et al. Treatment of Coronavirus Disease 2019 Patients with Convalescent Plasma Reveals a Signal of Significantly Decreased Mortality. Am J Pathol. 2020 Nov;190(11):2290-2303. doi: 10.1016/j.ajpath.2020.08.001. Epub 2020 Aug 11. PMID: 32795424; PMCID: PMC7417901.

38- Mair-Jenkins J, Saavedra-Campos M, Baillie JK, et al. The effectiveness of convalescent plasma and hyperimmune immunoglobulin for the treatment of severe acute respiratory infections of viral etiology: a systematic review and exploratory meta-analysis. J Infect Dis 2015;211:80-90. 
medRxiv preprint doi: https://doi.org/10.1101/2020.12.08.20246173; this version posted December 11, 2020. The copyright holder for this preprint (which was not certified by peer review) is the author/funder, who has granted medRxiv a license to display the preprint in perpetuity.

It is made available under a CC-BY-NC-ND 4.0 International license .

39- Hung IFN, To KKW, Lee $\mathrm{CK}$, et al. Hyperimmune IV immunoglobulin treatment: a multicenter double-blind randomized controlled trial for patients with severe 2009 influenza $A(H 1 N 1)$ infection. Chest 2013;144:464-73

40- Gamberini L, Tonetti T, Spadaro S, et al. ICU-RER COVID-19 Collaboration. Factors influencing liberation from mechanical ventilation in coronavirus disease 2019: multicenter observational study in fifteen Italian ICUs. J Intensive Care. 2020 Oct 15;8:80. doi: 10.1186/s40560-020-00499-4. PMID: 33078076; PMCID: PMC7558552. 
medRxiv preprint doi: https://doi.org/10.1101/2020.12.08.20246173; this version posted December 11, 2020. The copyright holder for this preprint (which was not certified by peer review) is the author/funder, who has granted medRxiv a license to display the preprint in perpetuity.

It is made available under a CC-BY-NC-ND 4.0 International license .

Acknowledgements - The authors would like to thank EV Souza for the statistical analysis and advise, also to the following physicians for referring their patients to this study: ALP Albuquerque, AC Nicodemo, D Deheinzelin, E Negri, LFL Carvalho, LF Cardoso, MAR Cuoco, P Seferian-Junior, R Kairalla, T Pfiffer, Y Novis, H Souza, T Zinsly, A Pacheco, G Johanson, FT Moreira, S Santoro, B Normandia, RM Carraro, E Meyer, A Lichtentstein, F Bacal, M Amar, CAF Santos, D Gondenberg, A Jaime, M RodriguesJunior, S Filizola, H Bacha, H Bogossian, C Hoelz, M Erlichman, E Pfefferman, R Kondo, MH Kuwakino, R Peres, GL Bub, DS Levi and FG Menezes.

Author contribution - Conceptualization: JMK, SW, APHY, RMF, CBB; investigation: JMK, SW, APHY, RMF, CBB, GC, PS, RA, MAB, RRGM, DBA, ELD.; formal analysis: JMK, SW, APHY, RMF, CBB, ARM; resources: LFLR, LVR writing: APHY, SW, JMK, CBB. 